\title{
Exploration of the New Mode of Integrating Ideological and Political Education with Industry-University-Research in the Cultivation of Innovative Ability of Medical Postgraduates in Ethnic Areas
}

\author{
Ying Zhang1*, Yan Li1 ${ }^{*}$, Jie Wang², Yan-E Zhou', Longjian Huang1, Bo Ling1, Xianjiu Liao1\#, \\ Qianli Tang1\# \\ ${ }^{1}$ Youjiang Medical University for Nationalities, Baise, China \\ ${ }^{2}$ Youjiang Medical University for Nationalities Affiliated Hospital, Baise, China \\ Email: "htmgx919@163.com, "1xj2006910@163.com
}

How to cite this paper: Zhang, Y., Li, Y., Wang, J., Zhou, Y.-E, Huang, L. J., Ling, B., Liao, X. J., \& Tang, Q. L. (2021). Exploration of the New Mode of Integrating Ideological and Political Education with Industry-University-Research in the Cultivation of Innovative Ability of Medical Postgraduates in Ethnic Areas. Advances in Applied Sociology, 11, 213-221.

https://doi.org/10.4236/aasoci.2021.114018

Received: April 23, 2021

Accepted: April 27, 2021

Published: April 30, 2021

Copyright ( 2021 by author(s) and Scientific Research Publishing Inc. This work is licensed under the Creative Commons Attribution International License (CC BY 4.0).

http://creativecommons.org/licenses/by/4.0/

\begin{abstract}
Objective: To explore new methods and functions of the new model of ideological and political education integrating production, teaching and research in the cultivation of medical graduates' innovative ability in ethnic areas. Methods: Starting from the status quo of the innovation ability of medical postgraduates in ethnic areas, it deeply analyzes the requirements of the innovation ability of medical postgraduates in ethnic areas under the background of the new era. Based on the actual situation of medical schools in ethnic regions, combined with the new model of ideological and political education integrating production, teaching and research, it analyzes its new methods and functions in promoting graduate students' innovative capabilities. Results: The new model of ideological and political education integrating production, education and research can realize the improvement of students' internal driving force, the rationality of the teaching staff, the optimization of platform resources, the standardization of system construction, and the high-level and applicability of scientific research results. Conclusion: The new model of ideological and political education integrating production, teaching and research is a powerful boost for the standardized training and innovation of medical graduate students in ethnic areas.
\end{abstract}




\section{Keywords}

Medical Postgraduates in Minority Areas, Innovative Ability, Ideological and Political Education, IUR (Industry-University-Research)

\section{Introduction}

The construction of innovative ability still remains the key and difficult point of the reform in the postgraduate education and cultivation of medical colleges in minority areas (minority areas refer to areas where ethnic minorities live together. China's ethnic minorities are mainly distributed in border areas such as the west and the north.) (Chen, Jing, Mo, Li, \& Huang, 2019). As the combination of science and technology and production practice of the primary productive force, the rapid development and transformation of scientific and technological innovation in a new era, which highlights the competitiveness of core original technologies and the service function of local economy, proposes higher requirements for the innovative ability cultivation of contemporary postgraduates (Luo \& Gao, 2020). The IUR mode is an advanced system in which industries, schools and scientific research institutions cooperate with each other, give full play to their respective advantages, and form a strong integration of research, development and production (Yang, 2019). The IUR mode can make full use of the resources of schools, scientific research institutes and enterprises, and provide systematic support for the cultivation of medical postgraduates, such as platform, technology and project. The integration of ideological and political education with the new IUR mode is to give full play to the advantages of the IUR mode in teaching staff, platform resources and achievements transformation under the coordination of ideological and political education while promoting the internal driving force of postgraduates and the standardization of system construction, so as to enhance the innovation ability of medical postgraduates in minority areas (Sun, 2020). Therefore, promoting the development of the integration of ideological and political education with IUR mode is a potentially important approach to improve the quality and standardization of medical postgraduate training in minority areas, and will also provide important support for the development of postgraduate education in China and the development of medical and health services in minority areas.

\section{New Requirements for the Innovative Ability of Medical Postgraduates in Minority Areas in the New Era}

Medical Postgraduates in ethnic minority areas are medical postgraduates studying in Colleges and universities in ethnic minority areas. Due to the relatively backward economic development, the discipline strength, scientific research level and platform construction of universities in ethnic minority areas are relatively backward, which leads to the deficiency of medical postgraduate education. However, with the rapid development of medical and higher education in 
China, the innovation ability of medical graduate students is increasing. The contradiction between the lack of school running level and the improvement of innovation ability is increasingly acute. Starting from the situation of medical postgraduates in ethnic areas, this paper systematically analyzes the new requirements of innovation ability of medical postgraduates in ethnic areas in the new era, which will provide a feasible direction for finding new innovation mode to solve problems.

\subsection{Standardization of Clinical Skills}

As one of the core assessment indicators of medical postgraduates, the standardized degree of clinical skills is also a significant magnification of their professional abilities (Han, 2015). With the rapid development of China's medical system, stricter and more standardized clinical skills of medical postgraduates in minority areas are required. Especially the prevention and treatment of sudden and serious disease play a crucial role in the standardization of clinical skills. The standardized clinical skills and operations provide favorable support for the effective prevention and control of COVID-19 in the process of its prevention and control in China. Therefore, standardized clinical skills are the basis for the improvement of the innovative ability of medical postgraduates in minority areas.

\subsection{Proficiency of Experimental Skills}

The training of scientific research ability occupies an important part in the training system of medical postgraduates. And the proficiency of experimental skills is the foundation for the scientific research ability. Currently, the research and development of high-tech products and the development of original scientific and technological theories in the medicine and health field in our country have put forward higher requirements for the cultivation of experimental skills for medical postgraduates (Ma, Du, Wu, Lai, \& He, 2012). First of all, in specific technical links, such as pcR, Western blot and other conventional technologies, it is not only focused on the use of medical postgraduates, but also more reflected in students' understanding of the principle of technology development and flexible adjustment of different experimental details, thus improving students' proficiency and proficiency in specific technologies. Meanwhile, interdisciplinary integration has become the mainstream trend of the cutting edge of medical currently, and various experimental skills involving different disciplines have been essential for medical postgraduates, such as: clinical data analysis, tests of nucleic acid test and antibody test, histological test in pathophysiology, cell culture and functional phenotype research in cell biology. Hence, the proficiency of experimental skills and the integration of various experimental skills put forward higher requirements for the cultivation of innovative ability of medical postgraduates in minority areas.

\subsection{Specialization of Thesis Writing}

The graduation thesis design of medical postgraduates is the most important 
component and assessment system in postgraduate education. Thesis writing is an important way for the professional knowledge mastery, experimental skills embodiment and scientific research achievements presentation of medical postgraduates. With the development of postgraduate education in China, the requirements for postgraduate thesis writing tend to be more rigorous and professional. The thesis of medical postgraduates is not only increasingly strict in logic, authenticity and repetition rate, but also has considerably high requirements for the quality and professional level of the thesis themselves (Si \& He, 2020). The specialization of the thesis is more reflected in whether the author's analysis and discussion of his professional knowledge background, experimental methods and results are consistent with the future development trend of the major, thus meeting the needs of the country for theoretical innovation and the transformation and application of science and technology. Therefore, the specialization of thesis writing is one of the important links of cultivating the innovative ability of medical postgraduates in minority areas besides logicality, authenticity and repetition rate.

\subsection{Application of Scientific and Technological Achievements}

"Transforming scientific and technological achievements to serve local development" is one of the important social functions of medical colleges and universities in minority areas. As the main force in overcoming difficulties and obtaining scientific and technological achievements, medical postgraduates play an important role in promoting the transformation of science and technology. In the reform of postgraduate education, promoting the construction of professional master's degree programs and highlighting the evaluation function of applied achievements have become one of the key directions (Wang, Liu, Gu, \& Mao, 2017). The applied evaluation has become one of the new evaluation systems among the achievements of medical postgraduates. Application should be highlighted in the specific study of scientific problems; at the same time, the guiding significance of the research results to the actual production practice has become one of the important contents in the cultivation of innovative ability of medical postgraduates in minority areas.

\section{Innovative Measures to Integrate Ideological and Political Education with the New IUR Mode}

\subsection{Enhance Students' Internal Driving Force}

The lack of internal driving force of students' own learning and innovation is an important factor that affects the improvement of innovation ability of medical postgraduates in minority areas. The value leading and educational function of ideological and political education can be exerted in the new IUR mode; At the same time, with the example of IUR mode, this thesis points out the feasible direction and method for the development of students' innovative ability. In terms of ideological and political education, it can be carried out in an orderly manner 
in the weekly regular work meeting from two aspects of the mission shouldered by medical postgraduates in minority areas and the cases of outstanding medical postgraduates. For example (Xi, 2016): The study of "General Secretary Xi Jinping's Speech at the National Science and Technology Innovation Conference, the General Assembly of Chinese Academy of Sciences and the Chinese Academy of Engineering, and the Ninth National Congress of the China Association for Science and Technology" can be further strengthened in the ideological and political module of the regular work meeting. Meanwhile, the examples of outstanding medical postgraduates who obtained national scholarships can be taken as sharing content ( $\mathrm{Li} \& \mathrm{Xu}, 2017$ ). The above two parts of learning will play a leading role in the innovation value of medical postgraduates. With excellent cases as a breakthrough, the contributions and the cultivated innovative ability of postgraduates, which are excellent cases, can be taken as an example in the IUR module to further enhance the internal driving force of innovation of medical postgraduates in minority areas.

\subsection{Rationalization of Teaching Staff}

The teaching staff of postgraduates in medical college of minority areas are teachers of colleges and universities, physicians and researchers in general. The lack of teachers for practical skills training still remains a problem while the learning needs of medical postgraduates in theory, clinical skills, experimental skills and scientific research are guaranteed. The application of IUR mode can incorporate high-level talents in the industry into the training system of medical postgraduates to solve the above problems (Zhao, Yang, Li, Dan, \& Guo, 2017). However, industrial talents, with heavy working tasks but no responsibility restraint system, cannot give full play to the role as teaching staff of postgraduate. Ideological and political education can give full play to the role of "the CPC's management over talents" by establishing cooperative relationship with the Party branch of cooperative unit. It can also promote the integration of industrial talents into the postgraduate education system through various forms such as thematic education, ideological mobilization and cooperation and exchange. In particular, unified and coordinated management should be further clarified in the work details and responsibilities of industrial talents (Xue, 2021), so as to further rationalize the teaching staff of medical postgraduate training in minority areas.

\subsection{Optimization of Platform Resources}

Few experimental platforms in medical colleges in minority areas have always mattered the training of medical postgraduates. The construction of new experimental platforms in medical colleges in minority areas is relatively slow on account of the limited school-running fund and regional economic differences. With the rise of IUR mode, the experimental platform of cooperative units can provide strong support for postgraduate training in medical colleges and universities in minority areas (Ren, Zhang, Luo, Luo, \& Wu, 2017). However, colleges 
and universities, hospitals, scientific research institutes and enterprises have different positioning and application of the experimental platform in the process of platform resource integration and optimization. Taking ideological and political education as a breakthrough, giving full play to the leading role of the Party, eliminating differences and unifying ideas in the use of the experimental platform. Clarify and refine the use of the platform, especially plan the use time and authority of graduate students (Yi \& Zou, 2015). Complementary advantages of platform resources, provide effective assistance for the cultivation of innovative ability of medical postgraduates in minority areas.

\subsection{Standardization of System Construction}

The improvement and standardization of system construction is the core guarantee for the innovative ability of medical postgraduates in minority areas (Zhang, 2015). The effective application of IUR mode can indeed provide important support for postgraduate training in medical colleges and universities in minority areas. However, there is still a lack of a very sound and standardized system. With ideological and political education as the core and the provisions of the state as the basis and criterion, it highlights the leadership of the Party and gives full play to the role of the Party Committees of both sides of the cooperation. On the premise of considering the actual situation of both sides and the cultivation of postgraduates' innovative ability, it finally reaches an agreement to formulate and promulgate a sound and standardized system of "medical postgraduates' cultivation under the mode of IUR" through effective communication and negotiation (Chen, He, Sun, \& Chen, 2020). From the training time, methods, platform use, project support and tutor responsibility of students and many other aspects, the paper makes a detailed analysis, so as to implement the cultivation of medical postgraduates' innovative ability in minority areas.

\subsection{High Level and Applicability of Scientific and Technological Achievements}

The premise of scientific and technological transformation of medical colleges and universities in minority areas is the high level and applicability of scientific and technological achievements. The optimization of resources in colleges and universities, hospitals, scientific research institutions and enterprises will be an effective driver to promote the high-level and applicable scientific and technological achievements of medical colleges in minority areas through IUR mode. As the main beneficiary of scientific and technological innovation and achievement acquisition, the innovation ability of medical postgraduates in minority areas will be further effectively improved (Wu, Chen, \& Huang, 2018). However, the extensive and orderly development of the IUR mode is inseparable from the support of ideological and political education. The mode of ideological and political education can give full play to the power of the Party and government of both sides of the cooperation. It will especially provide direction and guiding opinions in major issues such as the needs of regional medical care, economic 
and social development, which is one of the prerequisites for promoting the high-level and applied scientific and technological achievements of both sides of the cooperation (Cheng, Liu, \& Zhang, 2019). At the same time, in the process of transformation of scientific and technological achievements, the cultivation of students' innovation ability will be further exercised, especially in the whole technical system of laboratory technology moving towards product workshop (Zhang \& Long, 2019). Therefore, the new mode of integrating ideological and political education with IUR is one of the effective methods to promote the transformation of science and technology in medical colleges of minority areas and enhance the innovative ability of postgraduates.

\section{Conclusion}

The new mode of integrating ideological and political education with IUR is one of the feasible ways to cultivate the innovative ability of medical postgraduates in minority areas. This thesis analyzes the challenges faced by medical postgraduates in minority areas in cultivating their innovative ability from four dimensions: clinical skills, experimental skills, thesis writing and scientific and technological achievements. Focusing on the new mode of integrating ideological and political education with IUR, it will realize its advantages in improving students' internal driving force, rationality of teaching staff, optimization of platform resources, standardization of system construction, high-level and applicability of scientific research achievements to further promote the innovation ability of medical postgraduates in minority areas.

\section{Fund Program}

Innovation Project of Guangxi Postgraduate Education (Project No.: JGY2021214, JGY2019161, JGY2021219, JGY2020170); Construction project of case bank for professional degree postgraduate teaching in Youjiang Medical University for Nationalities (Project Name: Case Bank Construction of Surgery Teaching); Undergraduate Teaching Reform Project of Guangxi Higher Education (Project No.: 2018JGZ132, 2018JGA237).

\section{Conflicts of Interest}

The authors declare no conflicts of interest regarding the publication of this paper.

\section{References}

Chen, F., He, S., Sun, T., \& Chen, L. K. (2020). Research and Practice on the Joint Graduate Education Model of Industry-University-Research Cooperation. Education Teaching Forum, No. 18, 117-118.

Chen, Z., Jing, Y., Mo, S., Li, S., \& Huang, J. (2019). Preliminary Study on Innovative Training Mode of Basic Medical Postgraduates in Medical Colleges and Universities in Western Minority Areas-Taking Pathology and Pathophysiology of Youjiang Medical University for Nationalities as an Example. Journal of Youjiang Medical University for 
Nationalities, 41, 219-221.

Cheng, H., Liu, H., \& Zhang, S. (2019). Deep Integration of Industry, University and Research Promotes the Transfer and Transformation of Scientific and Technological Achievements in Colleges and Universities-Based on the Investigation and Analysis of 51 Universities and 88 Enterprises and Institutions. Chinese University Science \& Technology, No. 3, 4-8.

Han, Y. (2015). Clinical Is the Basic Research Is the Delayed Momentum-My View on the Training of Medical Postgraduates. Journal of Medical Postgraduates, 28, 1-3.

Li, W. L., \& Xu, Z. X. (2017). Exploration the Effect of the Innovative Network of Industry-University Research on the Cultivation of Talents in Colleges and Universities. Education Modernization, 4, 1-2+17.

Luo, Y., \& Gao, W. (2020). Exploration and Practice of Innovative Medical Postgraduate Training Mode under the Background of International Perspective. Education and Teaching Forum, No. 23, 223-225.

Ma, J., Du, X., Wu, X., Lai, J., \& He, L. (2012). Independent Experimental Design and Cultivation of Comprehensive Ability of Postgraduates in Basic Medical Education. Northwest Medical Education, 20, 54-55+82.

Ren, D., Zhang, S., Luo, B., Luo, R., \& Wu, C. (2017). Exploration and Practice of Cultivating Innovative Medical Postgraduates in Enterprise Postgraduate Workstations. Education and Teaching Forum, No. 5, 154-155.

Si, J., \& He, Y. (2020). Research on Writing Methods and Skills of Medical Postgraduates' Scientific Thesis-Taking North Sichuan Medical College as an Example. Journal of Higher Education, No. 21, 59-62.

Sun, D. (2020). Innovative Research on Teaching Methods of Ideological and Political Courses in Colleges and Universities under the Mode of Industry-University-Research. Journal of Hubei University of Education, 37, 32-36.

Wang, L., Liu, Y., Gu, H., \& Mao, J. (2017). Innovative Discussion on Training Postgraduates of Professional Master's Degree in Clinical Medicine. Journal of Postgraduate Medicine, 30, 193-195.

Wu, S., Chen, H., \& Huang, Q. (2018). Innovative Mode for the Construction of Research and Training Base for High-Level Medical Postgraduates-Taking West China Hospital of Sichuan University as an Example. Research and Exploration in Laboratory, 37, 200-202.

Xi, J. (2016). Speech at the National Science and Technology Innovation Conference, the General Assembly of Chinese Academy of Sciences and the Chinese Academy of Engineering, and the Ninth National Congress of the China Association for Science and Technology. Science and Technology Management Research, 36, 1-4.

Xue, D. (2021). The Research on the Innovation Path of the New Development Concept Embedded in the Party's Talent Management Work-Based on the Investigation of Jiangyin City, Jiangsu Province. The Forum of Leadership Science, No. 2, 100-103+116.

Yang, Z. (2019). The Status, Difficulties and Suggestions of Industry-University-Research Collaboration of Universities-Based on the Survey of 95 Universities. Journal of National Academy of Education Administration, No. 6, 75-82.

Yi, G., \& Zou, X. (2015). Study on Collaborative Innovation Platform of I-U-R-U Oriented to Strategic Emerging Industries. Research in Higher Education of Engineering, No. 2, 39-43.

Zhang, Y. (2015). Confusion and Challenge Brought by the Reform of Postgraduate Training System in Master of Clinical Medicine. Medical Education Management, 1, 
$205-207+210$

Zhang, Y., \& Long, M. (2019). Industry-University-Research Institute Collaboration in Marine Strategic Emerging Industries: Innovation Mechanism and Inspiration. Science and Technology Management Research, 39, 91-98.

Zhao, K., Yang, Y., Li, F., Dan, T., \& Guo, X. (2017). Exploration on the Training Mode of Professional Degree Postgraduates Based on the Joint Training System of Industry-University-Research. Degree and Postgraduate Education, No. 3, 44-49. 